University of Nebraska - Lincoln

DigitalCommons@University of Nebraska - Lincoln

Papers in the Earth and Atmospheric Sciences Earth and Atmospheric Sciences, Department

7-1896

\title{
The Occurrence in Nebraska of Vireo flavoviridis
}

Erwin Hinckley Barbour

University of Nebraska-Lincoln

Follow this and additional works at: https://digitalcommons.unl.edu/geosciencefacpub

Part of the Earth Sciences Commons

Barbour, Erwin Hinckley, "The Occurrence in Nebraska of Vireo flavoviridis" (1896). Papers in the Earth and Atmospheric Sciences. 335.

https://digitalcommons.unl.edu/geosciencefacpub/335

This Article is brought to you for free and open access by the Earth and Atmospheric Sciences, Department of at DigitalCommons@University of Nebraska - Lincoln. It has been accepted for inclusion in Papers in the Earth and Atmospheric Sciences by an authorized administrator of DigitalCommons@University of Nebraska - Lincoln. 
The Auk, Vol. 13, No. 3 (Jul., 1896), p. 263

Vol. XIII]

General Notes.

263

The Occurrence in Nebraska of Vireo flavoviridis.-A specimen of the Yellow-green Vireo, Vireo favoviridis, shot at Long Pine, Brown County, has just been received by the Curator of the Museum of the University of Nebraska. This is the first one reported in this State. It is a rare Vireo for the entire United States having been reported, as far as the author can learn, from Texas, California, and Canada only.

The specimen was shot and donated by the Rev. J. M. Bates of Long Pine, who has already done a great deal to further the knowledge of our native birds.

This adds one more to Prof. Lawrence Bruner's List of Nebraska Birds, recently published by the Nebraska State Horticultural Society. The total number of species and sub-species for the State is now 4I8.-ERwiN H. Barbour, University of Nebraska, Lincoln, Nebr. 